\title{
The Effect of EBA (Educational Informatics Network) Supported Mathematics Teaching on Student Achievement and Attitude in 5 th Grade Natural Numbers and Operations Unit
}

\author{
Harun Resit Vahit \\ Mathematics Teacher, Batman MEM, Batman, Turkey \\ E-Mail: harunresitvahit@gmail.com \\ Guler Tuluk \\ Kastamonu University, Faculty of Education, \\ Mathematics and Science Education, Kastamonu, Turkey \\ E-mail: gtuluk@gmail.com
}

\begin{abstract}
Instead of memorizing some rules, students can learn mathematics by structuring mathematical concepts and relations themselves in a social environment. In this study, it was aimed to examine the effect of 5th -grade students' mathematics teaching through teaching with EBA activities (lectures, exercises, scanning tests) on natural numbers, natural numbers, and operations on success and attitude in mathematics class. The experimental method was used in this research. A total of 138 fifth grade students, 72 experimental and 66 control group, participated in the study in a secondary school affiliated to a city center in the South East Anatolia region. The mathematics attitude scale and the mathematics achievement test developed by the researchers were used to collect data. There is no difference between the groups according to the mathematics pre-attitude scale. While the students in the control group were teaching by presentation, the experiment group was taught with EBA activities. The multiple-choice achievement test attitude scale related to the unit was applied before and after the application in the study, which lasted 38 lesson hours. The data obtained from the success test were evaluated using $3 \times 2$ repeated measures analysis of variance (ANOVA). The data obtained were analyzed with the SPSS 20.0 package program. Kolmogorov-Smirnov Z Test, Levene Test, and independent-sample t-test were used in the analysis of the data. At the end of the study, a significant difference in favor of the experimental group was found between the mathematics success and mathematics attitude posttest scores of the experimental group taught with EBA activities and the control group $(\mathrm{t}=6.437 ; \mathrm{p}=0.013,<0.05)$.
\end{abstract}

Keywords: Teaching mathematics, EBA, 5th-grade students

DOI: $10.7176 / \mathrm{JSTR} / 6-11-08$

\section{EBA (Ĕ̆itim Bilişim A ̆ğı) Destekli Matematik Öğretiminin 5. Sınıflar Doğal Sayılar ve İşlemler Ünitesinde Öğrenci Başarısına Ve Tutumuna Etkisi}

Özet

Öğrenciler birtakım kuralları ezberlemek yerine matematiği sosyal bir ortam içerisinde matematiksel kavram ve bağıntıları kendileri yapılandırarak öğrenebilirler. Bu çalışmada 5. sınıf öğrencilerinin Doğal sayılar, doğal sayılar ve işlemler konusunda EBA etkinlikleriyle yapılan öğretim ile sunuş yoluyla yapılan matematik öğretiminin matematik dersindeki başarıya ve matematiğe yönelik tutumlarına etkisinin incelenmesi amaçlanmıştır. Bu araştırmada deneysel yöntem kullanılmıştır. Çalışmaya, Güney Doğu Anadolu bölgesindeki bir il merkezine bağlı ortaokulda amaçlı örnekleme yöntemiyle belirlenmiş, 72 deney, 66 kontrol grubu olmak üzere toplam 138 beşinci sinıf öğrencisi 
katılmıştır. Veri toplamak amacıyla matematik tutum ölçeği ve araştırmacılar tarafından geliştirilen matematik başarı testi kullanılmıştı. Grupların arasında matematik ön tutum ölçeğine göre bir fark bulunmamaktadır. Kontrol grubundaki öğrenciler sunuş yoluyla ders işlerken, deney grubunda EBA etkinlikleriyle öğretim yapılmıştır. 38 ders saati süren çalışmada Uygulama öncesi ve sonrası, üniteyle ilgili çoktan seçmeli başarı testi tutum ölçeği uygulanmıştır. Başarı testlerinden elde edilen veriler $3 \mathrm{X}$ 2 tekrarlı ölçümler varyans analizi (ANOVA) kullanılarak değerlendirilmiştir. Elde edilen veriler SPSS 20.0 paket programı ile analiz edilmiștir. Verilerin analizinde Kolmogorov-Smirnov Z Testi, Levene Testi ve bağımsız örneklem t-testi kullanılmıştır. Araştırma sonunda EBA etkinlikleriyle öğretim yapılan deney grubu ile kontrol grubunun başarı sontest puanları arasında deney grubu lehine anlamlı fark bulunmuştur $(\mathrm{t}=6,437 ; \mathrm{p}=0,000<0,05)$. Ayrıca araştırma sonunda deney grubu ile kontrol grubunun matematiğe yönelik tutumlarında EBA etkinlikleriyle öğretim yapılan deney grubu lehine anlamlı fark bulunmuştur $(\mathrm{t}=2,509 ; \mathrm{p}=0,013<0,05)$.

Anahtar kelimeler: Matematik öğretimi, EBA, 5. Sınıf öğrencileri

\section{Giriș:}

Matematik; belirli bir sistem içerisinde mantıksal sıralamaya sahip, kavramlar ve işlemler üzerine kurulu örüntü ve düzen bilimidir. Bu örüntü ve düzeni keşfederek anlamlandırabilmek ve uygulamak ise tam olarak matematik yapmak demektir Matematiksel yeterliğin beş ana unsuru, i. Kavramsal anlama, ii. İşlemsel akıcılık, iii. Stratejik yetkinlik, iv. Uyarlanabilir muhakeme, v. Verimli eğilim olarak ifade edilir. Hesap makineleri, bilgisayarlar ve diğer teknolojiler sınıfta matematiğin öğrenimi ve yapımı için temel araçlar olarak görülmelidir. Teknoloji, öğrencilere akıl yürütmeleri ve matematiksel fikirleri başka konumlarda görme firsatı sağlar. (Van de Walle, Karp ve Bay-Williams, 2014). Çocuklardan beklediğimiz öğrenme türlerinin yetişkinlerle mümkün olan öğrenme türlerden nasıl farklı olması gerektiğini biliriz. Eğer öğrenme çevresi teknoloji açısından zenginse çocukların teknolojiden en iyi şekilde yararlanmaları için büyük sosyal değişimler, düzenlemeler gerçekleşir.

Öğrencilerin bilişsel yükünü azaltmak ve hazır bulunuşluk seviyeleri arasındaki farkı kapatabilmek adına çevrim içi kaynakların kullanımı iyi araştırılmalıdır. Özellikle matematik müfredatında bir sonraki seviyeye geçebilmek için hakim olunması gereken bir terminoloji ve kavram bolluğu vardır. $\mathrm{Bu}$ terimler ve kavramlar tam olarak anlaşılmadığında sonraki dersler için zayıf bir temel oluşturur. Çevrim içi ek kaynaklar öğrenmeyi arttırmak ve matematiksel kavramları derinleştirmek adına çeşitli eğitim stratejileri ve iyileştirme yöntemleri sunmaktadır (Seery ve Donnelly, 2012). Ayrıca öğrenciler çevrim içi kaynakları kullanım sürecinde öğrenme ortamlarını kendileri düzenlemektedirler. Vandewaetere ve Clarebout (2013) tarafindan yapılan çalışmada, öğrenme ortamlarını kendi ilgi alanlarına, ihtiyaçlarına ve yeteneklerine göre düzenleyen öğrencilerin tam veya kısmi yetkiye sahip olmaları, derslere karşı yüksek motivasyon göstermelerine olumlu yönde etki etmektedir. Çevrim içi kaynakların, geleneksel yöntemlere göre öğrenme ortamlarını yaratmadaki başarısı düşünülürse, matematiğe karşı olumsuz tutumun son derece yüksek olduğu eğitim sektöründe bu yönde atılacak adımlar önemlidir.

Milli Eğitim Bakanlığı FATİH Projesi kapsamında düzenlenen EBA bilişim portalında MEB'na ait eiçerikler, e-kitap, ses, video, görsel öğeler, animasyonlar, interaktif etkinlikler, e-testler, e-sınavlar, edeneme vb. birçok öğretim materyali bulunmakta ve içerik sağlayıcılar bunları güncellemektedir. EBA, web tabanlı olan eğitim erişiminde (Tüysüz, Aydın, 2007) karşımızda durmaktadır. Bu bağlamda, etkileşimli ortamlar (Seng ve Mohamad, 2002) eğitim açısından günümüzde çok değerlidir.

EBA, öğrenci ve öğretmenin kullanımına açıktır. 5. sınıfta sayılar ve işlemler alanında ilk ünite doğal sayılar ile doğal sayılar ve işlemler, 15 kazanım ve 38 saatlik süren 5. Sınıf programının \%22'lik kısmına tekabül eden bir durumdadır. 4, 5 ve daha üst sınıftaki öğrencilerin nasıl sayılabileceğinin ötesinde, sayıyla ilgili gerekli bilgiye ve donanıma sahip olmaları gerekmektedir. Ayrıca daha üst sınıflarda incelenecek olan üst düzey sayı kavramlarını tam olarak anlamaları için daha çok deneyime ve zamana ihtiyaçları olacaktır. (Van de Walle, Karp ve Bay-Williams, 2014). EBA her düzey için eiçerik sağlamaktadır. Öğrenci merkezli eğitim (Al, Madran, 2004) günümüzün ihtiyacıdır ve EBA bu konuda elimizdedir.

Zientek, Schneider ve Onwuegbuzie (2014), ilkokulda edinilmesi gereken ancak birçok öğrencide olmayan becerilerden birkaçını basamak değeri, çarpma olgusu ve kesirler olarak sıralamıştır. ABD'de lise mezunu olan öğrencilerin birçoğu, lisede cebir konularına yönelik eğitim almış olsalar da temel aritmetik, cebir öncesi işlem veya cebirsel işlemleri yapamamaktadır (Stigler, Givvin ve Thompson, 2014). 
Bağlamsal yapılarla ilişkilendirme (Oloruntegbe, Alam, 2010) ele alındığında EBA'da 5. Sınıflar doğal sayılar ve işlemler (konu anlatımı-videolar, alıştırma, tarama testi ve öğretmene özel bilgiler ) karşımızda durmaktadır. Sayı ilişkilerinin gerçek yaşam durumlarında uygulanması, evreni matematiksel bağlamda anlayabilmenin temelini oluşturmakta (Van de Walle, Karp ve Bay-Williams, 2014) ve EBA bu konuda bağlamsal bir anlatımla konuyu ele almaktadır. Bu yapının içinde gelişim dönemine uygun sayı kavramı ve sayı hissinin geliştirilmesine yönelik bir ilerleme vardır. Konu anlatımında üç video vardır ve iki video bağlamsal problemle ilerlemektedir. 2020 yllında bu videoların sayısı dört olmuştur. Çevrim içi yapının güncellenmesi de bu açıdan değerlidir. Konu anlatımlarında EBA'da bağlamsal problemlerle çalışmalara başlanmaktadır. Çalışmada bu bağlamsal problemlerin kalıcı olması açısından video izlendikten sonra öğrencilere bu videodaki sorulara ilişkin çalışma kâğıtları dağıtılmıştır. Dört işlemle ilgili problem yapıları EBA'da bağlamsal ve model temelli problemler olarak yer almaktadır.

Bilişsel bilgi işlem açısında yaklaştı̆ımızda öğrenme bilgi dizileri arasında bağlantılar oluşturmayı kazanma ve bellekte depolama ile öğrenmeyi kolaylaştırmadır. Öğrenciler bilginin etkin arayıcıları ve işleyicileridir. Çevrenin özelliklerini seçer ve ona dikkat ederler, bilgiyi aktarır ve tekrar ederler, yeni bilgiyi önceden edinilen bilgilerle ilişkilendirirler ve bilgiyi anlamlı hale getirmek için organize ederler (Mayer, 1996; Baki, 2008). Bilgi işleme bilişsel etkinlikler içinde yer alır. Bilişsel bilgi işleme duruma dayalı bilgi ve üst bilişsel olarak kavram öğrenme, problem çözme, stratejilerin kullanılması ve öz değerlendirmeyi içerir. Problem çözmeye ilişkin öğretim EBA'da öğrenmedeki anahtar süreçtir. Hatta bunu EBA'daki 5. Sınıf matematik derslerinin neredeyse tamamında görmek mümkündür.

Doğal sayılar ve işlemler bilişsel öğrenmeleri problem ç̧̈zmeye ilişkin öğretim üzerinden (öğrencilerin matematiği gerçek bağlamlar, problemler, durumlar ve modeller) soyutu kavrayabilmelerine zemin oluşturacak şekilde ilerlemektedir. Aynı şekilde alıştırma, tarama testleri ve öğretmene özel bilgilerle süreç işlenmeye devam etmektedir. Bu durum dört işlemin anlamlarının genişletilmesi, temel kuralların verilmesi, stratejilerin geliştirilmesi (toplama-çıkarma, çarpma ve bölme), bunlar yapıllırken öğrencilerin kendi icadı stratejilere yönelebilmesi için öğretmenin desteğine ihtiyaçları açıktır. Zihinden işlem, hesaplamaya dayalı tahmin ve birçok strateji kapsamın içinde öğretmenin önderliğinde ilerleyecektir.

Bu bağlamda çalışmada 5. sınıf "Doğal sayılar" konusunda üç kazanım ve "doğal sayılarda işlemler" konusunda 12 kazanımınaa yönelik "EBA üzerinden deney gubunda yapılan öğretim ile sunuş yoluyla öğretim yöntemi uygulanan kontrol grubu öğrencilerinin matematik başarıları ve matematiğe yönelik tutumları arasında anlamlı bir farklılık var mıdır?" probleminin cevabı araştırılmıştır.

\section{Yöntem}

Çalışma nicel araştırma olarak tasarlanmış ve araştırma problemine ilişkin veriler doğrultusunda EBA'nın öğrencilerin matematiğe yönelik tutum ve başarısı üzerindeki etkisini ve gruplar arasındaki farklılaşma boyutu incelenmiştir.

\section{Araştırma Modeli}

$\mathrm{Bu}$ çalışma nicel araştırma yöntemlerinden biri olan ön test-son test kontrol gruplu yarı deneysel desen olarak tasarlanmıştır. Bu desenle amaç, araştırmada değişkenleri (nicel olarak ölçülebilen ve farklı değerler alabilen özellikler) ölçebilmek ve bu değişkenler arasındaki sebep sonuç ilişkilerini ortaya çıkarmaktır. Çalı̧̧manın bağımsız değişkeni EBA destekli ve sunuş yoluyla yapılan öğretimdir. Bağımlı değişken matematik başarısı ve matematiğe yönelik tutumdur. Gruplarda her seviyede öğrenci olmasına dikkat edilmiştir (Ekiz, 2009). Bu bağlamda, araştırma deseni (Tablo 1) çok denekli ve çok faktörlü desenlerden karma desene göre yapılandırılmıştır (Büyüköztürk, 2001).

Tablo 1 GD: EBA destekli öğretimin yapıldığı deney grubu. GK: Sunuş yoluyla öğretimin yapıldığı kontrol grubu

\begin{tabular}{lccc}
\hline Gruplar & Ön Ölçümler & $\begin{array}{c}\text { Öğrenme } \\
\text { Ortamı }\end{array}$ & Son Ölçümler \\
\hline GD & Matematik Tutum & EBA Destekli & Matematik Tutum \\
& Ölçeği & Öğrenme Ortamı & Ölç̣i \\
Başarı Testi & & Başrı Testi \\
GK & Matematik Tutum & Sunuş Yoluyla & Matematik Tutum \\
& Ölçeği & Yapılan & Ölçeği \\
& Başarı Testi & Öğrenme Ortamı & Başarı Testi \\
\hline
\end{tabular}

81 | P a g e 


\section{Araştırma Grubu}

Araştırmanın grupları 2018-2019 eğitim-öğretim yılı güney doğu bölgesindeki bir il merkezinde sosyoekonomik açıdan düşük seviyede olan bir ortaokul da yapılmıştır. 5. Sınıflardan iki şube deney grubu (35 kız ve 37 erkek olmak üzere 72 öğrenci) ve iki şube kontrol grubu (30 kız ve 36 erkek olmak üzere öğrenci 66) olacak şekilde yansız olarak atanmışlardır.

\section{Ölçme Araçları}

Araştırma Kapsamında iki ölçme aracı kullanılmıştır. Bu ölçme araçlarından ilki araştırmacılar, öğretmen ve ve uzman görüşü alınarak hazırlanan "Matematik Başarı Testi” (MBT) testindeki sorular çoktan seçmeli olup 32 maddeden oluşmaktadır. MBT ilk olarak 55 maddeden oluşmuş, pilot olarak ortaokul altıncı sınıflara uygulanmış güvenirlik analizinden sonra 32 madde kalmış Cronbach's Alpha değeri 0,835 olarak bulunmuştur. Elde edilen bu güvenirlik katsayısına göre son hali verilen akademik başarı testinin güvenilir olduğu söylenebilir (Büyüköztürk, 2001).

MBT kapsamında incelenen kazanımlar ve kazanımlara yönelik madde numaralarını içeren belirtke tablosu Tablo 2'de sunulmuştur. Tablo 2 incelendiğinde MBT'de yer alan maddelerin kazanımlar doğrultusunda homojen olarak dağıldığı görülmektedir. $\mathrm{Bu}$ durumda hazırlanan testin kapsam geçerliğinin sağlandığ 1 belirtilebilir.

Tablo 2 Araştırmada Kullanılan Başarı Testi

\begin{tabular}{|c|c|c|}
\hline Kazanımlar & İlgili Sorular & $\begin{array}{l}\text { Soru } \\
\text { say1s1 }\end{array}$ \\
\hline 5.1.1.1. En çok dokuz basamaklı doğal sayıları okur ve yazar. & 1 ve 2 & 2 \\
\hline $\begin{array}{l}\text { 5.1.1.2. En çok dokuz basamaklı doğal sayıların bölüklerini, } \\
\text { basamaklarını ve rakamların basamak değerlerini belirtir. }\end{array}$ & 3 ve 4 & 2 \\
\hline $\begin{array}{l}\text { 5.1.1.3. Kuralı verilen sayı ve şekil örüntülerinin istenen } \\
\text { adımlarını oluşturur. }\end{array}$ & 5,6 ve 8 & 3 \\
\hline $\begin{array}{l}\text { 5.1.2.2. İki basamaklı doğal sayılarla zihinden toplama ve } \\
\text { çıarma işlemlerinde strateji belirler ve kullanır. }\end{array}$ & 19 & 1 \\
\hline $\begin{array}{l}\text { 5.1.2.3. Doğal sayılarla toplama ve çıkarma işlemlerinin } \\
\text { sonuçlarını tahmin eder. }\end{array}$ & 16 ve 20 & 2 \\
\hline $\begin{array}{l}\text { 5.1.2.4. En çok üç basamaklı iki doğal sayının çarpma işlemini } \\
\text { yapar. }\end{array}$ & 21 & 1 \\
\hline $\begin{array}{l}\text { 5.1.2.5. En çok dört basamaklı bir doğal sayıyı, en çok iki } \\
\text { basamaklı bir doğal sayıya böler. }\end{array}$ & 22 ve 32 & 2 \\
\hline $\begin{array}{l}\text { 5.1.2.7. Doğal sayılarla zihinden çarpma ve bölme işlemlerinde } \\
\text { uygun stratejiyi belirler ve kullanır. }\end{array}$ & 18 ve 24 & 2 \\
\hline $\begin{array}{l}\text { 5.1.2.8. Bölme işlemine ilişkin problem durumlarında kalanı } \\
\text { yorumlar. }\end{array}$ & 17,25 ve 26 & 3 \\
\hline $\begin{array}{l}\text { 5.1.2.9. Çarpma ve bölme işlemleri arasındaki ilişkiyi anlayarak } \\
\text { işlemlerde verilmeyen ögeleri (çarpan, bölüm veya bölünen) } \\
\text { bulur. }\end{array}$ & $11,14,28$ ve 29 & 4 \\
\hline $\begin{array}{l}\text { 5.1.2.10. Bir doğal sayının karesini ve küpünü üslü ifade olarak } \\
\text { gösterir ve değerini hesaplar. }\end{array}$ & 13,27 ve 30 & 3 \\
\hline $\begin{array}{l}\text { 5.1.2.11. En çok iki işlem türü içeren parantezli ifadelerin } \\
\text { sonucunu bulur. }\end{array}$ & 12 ve 23 & 2 \\
\hline 5.1.2.12. Dört işlem içeren problemleri çözer. & $7,9,10,15$ ve 31 & 5 \\
\hline
\end{tabular}

Ayrıca, Nazlıçiçek ve Erktin (2002) tarafından geliştirilen "Matematik Tutum Ölçeği” (MTÖ) kullanılmıştır. Ölçek 20 maddeden oluşan üç faktörlü likert tipinde bir ölçektir. 


\section{Uygulama Süreci-İşlem}

Çalışma kapsamında uygulama süreci toplam 8 hafta ve 38 ders saati (her bir ders saati 40 dakikadır) olarak tasarlanmıştır. Ulaşılması istenen 15 kazanım deney ve kontrol gruplarında paralel olarak yürütülerek aynı zamanda bitirilmiştir.

\section{Deney Grubunda Gerçekleştirilen İşlemler}

Deney grubunda araştırmacı tarafından öğretim müfredatında yer alan Doğal sayılar konusunun kazanımlarına ilişkin EBA üzerinde ders anlatımlarına ve etkinliklere dayalı ders planları hazırlamıştır. MEB (2018) beşinci sınıf öğretim programı dikkate alındığında bu konuya ait 15 kazanımın olduğu görülmektedir. $\mathrm{Bu}$ kazanımların öğretimine yönelik bu çalışmada gerçek hayat ilişkilendirilmesi bağlamında örneğin "M.5.1.1.1. En çok dokuz basamaklı doğal sayıları okur ve yazar" kazanımı İstanbul şehrinin nüfusu üzerinden işlenmektedir. Gerçek hayat durumları ile ilişkilendirme ve somutlaştırma bağlamında EBA ders içeriklerinin kullanımı ile ilgili bu animasyon ve etkinlikler Çakır'ın (1999) çalışmasında belirttiği şekildedir. Bu çalışmada da animasyonların öğrencinin ders konularını somut olarak izlemelerini sağlamış disiplinler arası olarakta sosyal bilgiler coğrafya dersi ile ilişkilendirilmiştir. Ayrıca yaşam bilimlerinden biyoloji ile ilişkilendirilerek basamaklarda bulunan rakamın sıfır olduğunda sayının nasıl okunacağı animasyonla gösterilmiştir. Bu şekilde kavramı matematiksel olarak anlamalarının yanında becerilerden disiplinler arası ilişkilendirme sağlanmıştır. Ayrıca 5. Sınıf öğrencilerinin internette arama yaparken anahtar kelime kullanma ile ilgili bir uygulama görmeleri de sağlanmıştır. Bu yaklaşımlar ışı̆̆ında bu çalışmanın deney grubunda daoğal sayılar konusuna ilişkin öğretim materyali olarak EBA platformu üzerinde yer alan animasyonlar, etkinliklerle sayının basamak ve bölüklerine ayrılarak okunması sağlanmıştır.

Deney grubunda araştırmacılar tarafından öğretim müfredatında yer alan Doğal sayılarda işlemler konusunun kazanımlarına ilişkin EBA üzerinde videolarla yapılan ders anlatımlarına ve etkinliklere dayalı ders planları ve öğrenci çalışma kâğıtları hazırlanmıştır. Ek 1'dekine benzeyen bu çalışmalar işlemler konusunda toplama ve çıkarma, çarpma ve bölme işlemleri, zihinden işlemler ve tahmine yönelik videolarla devam etmiştir. Doğal sayılarda hesaplamaya dayalı stratejilerin geliştirilmesi konusunda araştırmacının ders içindeki önemi öğrenci icadı stratejilerin geliştirilmesi konusundaki süreçte çok önemli olmuştur. Ortam çevrim içi olmakla birlikte dersin içinde işlemlere ve tahmine yönelik stratejilerin geliştirilmesinde öğretmenin rolü açıktır. Akışta bir sayının karesi ve küpü, parantezli işlemlerle ilgili ilerleyiş daha sonra bağlamsal problemlerle ve bu problemlerin çözümündeki stratejilerle devam etmektedir. Örneğin, "Elif orman haftasında 3 gün süren bir ağaç dikme etkinliğine katılıyor. Bu etkinlikte her gün 5 tane çam fidanı, 2 tane de meşe fidanı dikiyor. Bu etkinliğin sonunda Elif toplam kaç tane fidan dikmiştir?" problemi.

EBA'daki “doğal sayılar ve doğal sayılarda işlemler ünitesi” MEB’nın yayınladığı 5. Sınıf matematik ders kitabındaki (Cırıtcı, Gönen, Araç, Özarslan, Pekcan, Şahin, 2018) çalışmalarla uyumludur. Araştırmacının ders veren öğretmen olduğu bu süreçte öğrenciler EBA platformunu aktif bir şekilde kullanmışlardır. Ayrıca öğrencilere "Neden?", "Nasıl?”, "Niçin”, "Şimdi Ne Yapılmalı?” soruları ile onların matematiksel düşünme ve matematiksel okur-yazarlık süreçlerine katkı verilmiştir.

\section{Kontrol Grubunda Gerçekleştirilen İşlemler}

Kontrol grubunda da araştırmacı dersin öğretmenidir. Sunuş yoluyla öğretim müfredat doğrultusunda gerekli bilgilerin tahtada öğretmen tarafından anlatılıp, öğrencilere yazdırılması gibi düz anlatımlar kullanılmıştır. Doğal sayılar ve doğal sayılarda işlemler ünitesi yıllık planda belirtildiği gibi anlatılmış, bilgi aktarıldıktan sonra öğrencilere kazanımlara ilişkin sorular sorulmuş tahtada çözüm yapılmış veya yaptırılmıştır. Araştırmacı hem kontrol hem de deney grubunda ayni öğretmendir.

\section{Bulgular}

Yapılan analizler sonucunda elde edilen bulgular, alt problemler dikkate alınarak tablolar yapılmış ve analiz sonuçlarına dayalı yorumlar yapılmıştır.

\section{Tutum Testi Puanları}

Tablo 1'de deney ve kontrol grubunda bulunan öğrencilerin ön ve son tutumları gösterilmektedir. 
Tablo 3 Matematik Ön ve Son Tutum Puanlarının Betimsel İstatistikleri

\begin{tabular}{|l|l|c|c|c|}
\hline & Grup & f & Ort. & Std. Sapma \\
\hline \multirow{3}{*}{ Ön Tutum } & Deney & 72 & 79,1343 & 11,91116 \\
\cline { 2 - 5 } & Kontrol & 66 & 78,2712 & 11,51885 \\
\hline \multirow{2}{*}{ Son Tutum } & Deney & 72 & 85,1940 & 10,00491 \\
\cline { 2 - 5 } & Kontrol & 66 & 80,1017 & 12,74646 \\
\hline
\end{tabular}

Gruplar arasında istatistiksel olarak anlamlı farklılık olup olmadığını belirlemek, hangi testin yapılacağına karar vermek için normal dağılım gösterip göstermediğine bakılmalıdır. Tablo 2 dağılımın normalliğini incelemektedir. Normal dağılım için Kolmogorov-Smirnov testi yapılmıştır. Bu test ile ilgili bulgular Tablo 2'de verilmiştir.

Tablo 4 Matematik Ön ve Son Tutum Puanlarının Normalliği

\begin{tabular}{|l|c|c|}
\hline & Ön Tutum & Son Tutum \\
\hline $\mathrm{n}$ & 138 & 138 \\
\hline Ortalama & 78,7302 & 82,8095 \\
\hline Std. Sapma & 11,69028 & 11,60808 \\
\hline Kolmogorov-Smirnov Z & 1,151 & 1,292 \\
\hline Anlamlilik (p) & 0,142 & 0,071 \\
\hline
\end{tabular}

Tablo 2'ye göre hem ön tutum puanlarının $p$ değeri $(\mathrm{p}=0,142)$ hem de son tutum puanlarının $\mathrm{p}$ değeri $(p=0,071) 0,05$ 'ten büyük olduğundan her iki veri setinin de normal dağıldığı görülmüştür. Bu nedenle deney ve kontrol gruplarının ön ve son tutumları arasında istatistiksel olarak anlamlı farklılık olup olmadığını belirlemek için parametrik testlerden bağımsız örneklem t testi yapılmıştır. $\mathrm{Bu}$ testin sonuçları Tablo 3'te verilmiştir.

Tablo 5. Deney ve Kontrol Gruplarının Matematiksel Tutumlarının Karşılaştırılması

\begin{tabular}{|l|l|c|c|c|c|c|}
\hline & & \multicolumn{2}{|c|}{$\begin{array}{c}\text { Varyans Eşitliği için } \\
\text { Levene Testi }\end{array}$} & \multicolumn{3}{c|}{$\mathrm{t}$ - testi } \\
\hline \multirow{2}{*}{ Ön tutum } & $\begin{array}{l}\text { Varyansların eşitliği } \\
\text { kabul edilirse }\end{array}$ & 0,012 & 0,911 & 0,412 & 136 & 0,681 \\
\cline { 2 - 7 } & $\begin{array}{l}\text { Varyansların eşit } \\
\text { olmadığı kabul edilirse }\end{array}$ & & & 0,413 & 136,896 & 0,680 \\
\hline $\begin{array}{l}\text { Son } \\
\text { tutum }\end{array}$ & $\begin{array}{l}\text { Varyansların eşitliği } \\
\text { kabul edilirse }\end{array}$ & 3,921 & 0,051 & 2,509 & 136 & 0,013 \\
\cline { 2 - 7 } & $\begin{array}{l}\text { Varyansların eşit } \\
\text { olmadığı kabul edilirse }\end{array}$ & & & 2,471 & 121,644 & 0,015 \\
\hline
\end{tabular}

Tablo 3'teki bulgular incelendiğinde deney ve kontrol gruplarının hem ön tutum hem de son tutum puanlarının varyanslarının eşit olduğu kabul edilebilmektedir (Fön tutum=0,012; pön tutum=0,911 > $0,05$; Fson tutum $=3,921$; p son tutum $=0,051>0,05)$. Böylece ön tutum için deney ve kontrol grupları arasında istatistiksel olarak anlamlı bir farklılık bulunmadığı saptanmıştır $(\mathrm{t}=0,412 ; \mathrm{p}=0,681>0,05)$. Buna karşın son tutum için deney ve kontrol grupları arasında istatistiksel olarak anlamlı bir farklılık görülmüştür ( $\mathrm{t}=2,509 ; \mathrm{p}=0,013<0,05)$.

Tablo 4'deki betimsel istatistiklere göre deney grubunun ortalama puanının $(\bar{x}=85,1940)$ kontrol grubunun ortalama puanından $(\bar{x}=80,1017)$ yüksek olduğu sonucuna ulaşılabilir. 
1. EBA destekli matematik öğretiminin yapıldığı deney grubu öğrencileri ile sunuş yoluyla öğretimin yapıldığı kontrol grubu öğrencilerinin, öğretim sonucunda matematiğe yönelik tutumlarında anlamlı bir fark var mıdır?" Problemine İlişkin Bulgular

Tablo 6. Matematik Tutum Son Test Puanlarının Betimsel İstatistikleri

\begin{tabular}{|l|l|c|c|c|}
\hline & Grup & f & Ort. & Std. Sapma \\
\hline \multirow{3}{*}{ Son Test } & Deney & 72 & 85,1940 & 10,00491 \\
\cline { 2 - 5 } & Kontrol & 66 & 80,1017 & 12,74646 \\
\hline
\end{tabular}

Tablo 4'den deney ve kontrol gruplarının matematik tutum son test puanları arasında istatistiksel olarak anlamlı farklılık olup olmadığını belirlemek için parametrik testlerden bağımsız örneklem testi yapılmıştır. Bu test ile ilgili bulgular Tablo 5'de verilmiştir.

Tablo 7. Deney ve Kontrol Gruplarının Matematik Tutum Son Test Puanlarına Göre Karşılaştırılması

\begin{tabular}{|l|l|c|c|c|c|c|}
\hline \multicolumn{2}{|c|}{} & \multicolumn{2}{|c|}{$\begin{array}{c}\text { Varyans Eşitliği için } \\
\text { Levene Testi }\end{array}$} & \multicolumn{3}{c|}{ t - testi } \\
\cline { 3 - 7 } \multicolumn{2}{|c|}{} & $\mathrm{F}$ & $\mathrm{p}$ & $\mathrm{t}$ & $\mathrm{sd}$ & $\mathrm{P}$ \\
\hline \multirow{2}{*}{$\begin{array}{l}\text { Son } \\
\text { test }\end{array}$} & $\begin{array}{l}\text { Varyansların eşitliği } \\
\text { kabul edilirse }\end{array}$ & 3,921 & 0,051 & 2,509 & 136 & 0,013 \\
\cline { 2 - 7 } & $\begin{array}{l}\text { Varyansların eşit } \\
\text { olmadığ1 kabul edilirse }\end{array}$ & & & 2,471 & 135,972 & 0,015 \\
\hline
\end{tabular}

Tablo 5'deki bulgular incelendiğinde deney ve kontrol gruplarının son test puanlarının varyanslarının eşit olduğu kabul edilebilmektedir $(\mathrm{F}=3,921 ; \mathrm{p}=0,051>0,05)$. Böylece son test için deney ve kontrol grupları arasında istatistiksel olarak anlamlı bir farklılık bulunduğu saptanmıştır $(\mathrm{t}=2,509 ; \mathrm{p}=0,013<$ 0,05). Puan ortalamaları doğrultusunda (Tablo 5) EBA destekli öğretim modelinin matematik dersine karşı olan tutumu, deney grubu lehine olumlu sonuçlanmıştır (Tablo 6).

\section{Başarı Testi Puanları}

Deneysel işlem öncesi ön test puanlarının normal dağılıma uygun olup olup olmadığı KolmogorovSmirnov testi uygulanarak kontrol edilmiştir. Bu test ile ilgili bulgular Tablo 6'da verilmiştir.

Tablo 8. Başarı Ön Test Puanlarının Normalliğinin İncelenmesi

\begin{tabular}{|l|c|}
\hline & Ön Test \\
\hline $\mathrm{n}$ & 138 \\
\hline Ortalama & 8,2899 \\
\hline Std. Sapma & 3,23124 \\
\hline Kolmogorov-Smirnov Z & 1,036 \\
\hline Anlamlilik (p) & 0,234 \\
\hline
\end{tabular}

Tablo 6'ya göre ön test puanlarının p değeri 0,234 > 0,05'ten büyük olduğundan ön test puanlarının normal dağıldığı görülmüştür. Bu nedenle deney ve kontrol gruplarının ön test puanları arasında istatistiksel olarak anlamlı farklılık olup olmadığını belirlemek için parametrik testlerden bağımsız örneklem t testi yapılmıştır. Bu test ile ilgili bulgular Tablo 7'de verilmiştir. 
Tablo 9 Deney ve Kontrol Gruplarının Başarı Ön Test Puanlarına Göre Denkliğinin Belirlenmesi

\begin{tabular}{|l|l|c|c|c|c|c|}
\hline & & \multicolumn{2}{|c|}{$\begin{array}{c}\text { Varyans Eşitliği için Levene } \\
\text { Testi }\end{array}$} & \multicolumn{3}{c|}{$\mathrm{t}$ - testi } \\
\hline & & $\mathrm{F}$ & $\mathrm{p}$ & $\mathrm{t}$ & $\mathrm{sd}$ & $\mathrm{p}$ \\
\hline \multirow{2}{*}{$\begin{array}{l}\text { Ön } \\
\text { test }\end{array}$} & $\begin{array}{l}\text { Varyansların eşitliği } \\
\text { kabul edilirse }\end{array}$ & 0,185 & 0,667 & $-0,942$ & 136 & 0,348 \\
\cline { 2 - 7 } & $\begin{array}{l}\text { Varyansların eşit } \\
\text { olmadığ kabul edilirse }\end{array}$ & & & $-0,943$ & 135,586 & 0,347 \\
\hline
\end{tabular}

Tablo 7'deki bulgular incelendiğinde deney ve kontrol gruplarının ön test puanlarının varyanslarının eşit olduğu kabul edilebilmektedir $(F=0,185 ; p=0,667>0,05)$. Böylece ön test için deney ve kontrol grupları arasında istatistiksel olarak anlamlı bir farklılık bulunmadığ 1 saptanmıştır $(\mathrm{t}=-0,942 ; \mathrm{p}=$ $0,348>0,05$ ).

2. EBA destekli matematik öğretiminin yapıldığı deney grubu öğrencileri ile sunuş yoluyla öğretimin yapıldığı kontrol grubu öğrencilerinin, öğretim sonucunda matematiğe yönelik başarılarında anlamlı bir fark var mıdır?” Alt Problemine İlișkin Bulgular

$\mathrm{Bu}$ alt problemi test etmek üzere son test, deney ve kontrol gruplarına deneysel işlem sonrası uygulanmıştır. Deney ve kontrol grubunda bulunan öğrencilerin matematik son test puanlarının betimsel istatistikleri Tablo 8'de verilmiştir.

Tablo 10. Matematik Başarı Son Test Puanlarının Betimsel İstatistikleri

\begin{tabular}{|l|l|c|c|c|}
\hline & Grup & f & Ort. & Std. Sapma \\
\hline \multirow{3}{*}{ Son Test } & Deney & 72 & 17,1389 & 5,39772 \\
\cline { 2 - 5 } & Kontrol & 66 & 11,4848 & 4,87456 \\
\hline
\end{tabular}

Deney ve kontrol grubunda bulunan öğrencilerin son test puanları arasında istatistiksel olarak anlamlı farklılık olup olmadığını belirlemek için hangi testin yapılacağını belirlemek amacıyla öncelikle normal dağılım gösterip göstermediği Kolmogorov-Smirnov testi ile belirlenmiştir. Bu test ile ilgili bulgular Tablo 9'da verilmiştir.

Tablo 11. Başarı Son Test Puanlarının Normalliği

\begin{tabular}{|l|c|}
\hline & Son Test \\
\hline $\mathrm{n}$ & 138 \\
\hline Ortalama & 14,4348 \\
\hline Std. Sapma & 5,86584 \\
\hline Kolmogorov-Smirnov Z & 1,113 \\
\hline Anlamlilik (p) & 0,168 \\
\hline
\end{tabular}

Tablo 12. Deney ve Kontrol Gruplarının Matematik Başarı Son Test Puanlarına Göre Karşılaştırılması

\begin{tabular}{|c|l|c|c|c|c|c|}
\hline & & \multicolumn{4}{|l|}{$\begin{array}{l}\text { Varyans Eşitliği için } \\
\text { Levene Testi }\end{array}$} & \multicolumn{2}{l|}{ - testi } \\
\hline & & $\mathrm{F}$ & $\mathrm{p}$ & $\mathrm{t}$ & $\mathrm{sd}$ & $\mathrm{p}$ \\
\hline $\begin{array}{l}\text { Son } \\
\text { test }\end{array}$ & $\begin{array}{l}\text { Varyansların eşitliği } \\
\text { kabul edilirse }\end{array}$ & 0,829 & 0,364 & 6,437 & 136 & 0,000 \\
\cline { 2 - 7 } & $\begin{array}{l}\text { Varyansların eşit } \\
\text { olmadı̆̆ kabul } \\
\text { edilirse }\end{array}$ & & & 6,466 & 135,972 & 0,000 \\
\hline
\end{tabular}


Tablo 10'daki bulgular incelendiğinde deney ve kontrol gruplarının son test puanlarının varyanslarının eşit olduğu kabul edilebilmektedir $(\mathrm{F}=0,829 ; \mathrm{p}=0,364>0,05)$. Böylece son test için deney ve kontrol grupları arasında istatistiksel olarak anlamlı bir farklılık bulunduğu saptanmıştır $(\mathrm{t}=6,437 ; \mathrm{p}=0,000<$ $0,05)$.

Tablo 10'daki betimsel istatistiklere göre deney grubunun ortalama puanının ( $\bar{x}=\mathbf{1 7 , 1 3 8 9}$ ) kontrol grubunun ortalama puanından $(\bar{x}=11,4848)$ yüksek olduğu sonucuna ulaşılabilir. Ortalama puanların doğrultusunda uygulanan öğretim yöntemlerinden EBA destekli öğretim yöntemi, sunuş yoluyla öğretim yöntemine göre öğrencilerin akademik başarılarını anlamlı olarak etkilemiştir.

\section{Sonuçlar}

$\mathrm{Bu}$ arastırmada, EBA'ya dayalı ve sunuş yoluyla yapılan öğretimin sonucunda ortaokul beşinci sınıf öğrencilerinin matematik başarısı, matematiğe yönelik ve teknolojiye yönelik tutumları incelenmiştir.

Uygulanan başarı testi 32 puan üzerinden değerlendirildiğinde, deney grubunun son test ortalaması 17,1389'a kadar yükselmiş ve kontrol grubunun ortalaması da 11,4848'e kadar yükselebilmiştir. Ayrıca bu durum, genel anlamda deneklerin matematik başarılarının çok düşük seviyede olduğunu göstermektedir.

Doğal sayılar, doğal sayılarda işlemler için matematik başarı ön test ve son test sonuçları: deney grubuna uygulanan EBA destekli etkinliklerle yapılan öğretimin öğrencilerin başarı puanlarının arttırılmasında etkili olduğu ortaya kondu. Başka bir deyişle, çıkarımsal istatistiklerin sonuçları, EBA destekli etkinliklerle yapılan öğretimin lehine Doğal sayılar, doğal sayılarda işlemler ünitesindeki başarı testlerinin deney ve kontrol grubundaki öğrencilerin ortalama puanları arasında anlamlı farklılıklar olduğunu göstermiştir.

Akbaş'ın (2019), 5.sınıf öğrencilerinin EBA destekli kesirlerde işlemler konusu özelinde akademik başarılarına etkisi deney grubu lehine olan çalışmanın bulgusu ve Açıkgöz'ün (2018) EBA destekli matematik öğretiminin 7.sınıf öğrencilerinin cisimlerin farklı yönlerden görünümleri konusundaki akademik başarılarına etkisi deney grubu lehine olan çalışmalarının bulgusu yapılan bu çalışmanın bulgularıyla uyumludur. Aynı şekilde, Cengiz'in (2017) çalışmasında da ortaokul 7.sınıf çokgenler konusunun bilgisayar, akıllı tahta, GeoGebra dinamik geometri yazılımı ve eğitim bilişim ağı (EBA) yardımıyla işlenmesinin matematikteki başarıya etkisi deney grubu lehinedir.

Bir diğer çalışmada Gündüz ve Kutluca (2019), matematik öğretiminde akıllı tahta kullanımının öğrencilerin akademik başarısına etkisini araştırmışlar, meta-analiz yöntemiyle birleştirilen sonuçlara göre akademik başarı artışında olumlu yönde ve geniş kapsamda etkinin olduğu sonucunu ortaya çıkarmışlardır.

Bilgin (2018), orta öğretim matematik dersi programında yer alan veri alt öğrenme alanına yönelik teknoloji destekli öğrenme ortamlarının etkisini deney grubu lehine anlamlı bulmuştur.

Murphy, Gallagher, Krumm, Mislevy ve Hafter (2014) tarafından yürütülen ve EBA benzeri bir öğrenme nesnesi olan Khan Academy’nin etkisini araştırmak üzere yirmi okul ve yetmiş öğretmen üzerinde iki yıl süren bir araştırma yapmışlardır. Araştırma nitel ve nicel olarak çalışıldığından karma model kullanılmıştır. Khan Academy'yi sınıfta ek bir eğitim kaynağı olarak kullanmanın öğrencilerin daha fazla sayıda problemi çözebilmeyi, daha çok çözüm stratejisi geliştirebilmeyi sağladığı görülmüştür.

Kelly (2018) günde onbeş dakika Khan Academy kullanılarak öğretim yapılan 9.sınıf öğrencilerinin matematik başarısında etkisini incelemiştir. İki farklı kırsal lisede yapılan çalışmada ön test-sontest kontrol gruplu yarı deneysel model kullanılmıştır. Veriler Khan Academy kullanılarak uygulanan öğretim modelinin deney grubu üzerinde anlamlı bir etkiye sahip olmadığını göstermiştir.

Doğal sayılar, doğal sayılarda işlemler için matematiğe yönelik tutum ön test ve son test sonuçları: deney grubuna uygulanan EBA destekli etkinliklerle yapılan öğretimin öğrencilerin matematiğe yönelik tutumlarının arttırılmasında etkili olduğu ortaya kondu. Başka bir deyişle, çıkarımsal istatistiklerin sonuçları, EBA destekli etkinliklerle yapılan öğretimin lehine Doğal sayılar, doğal sayılarda işlemler ünitesindeki matematiğe yönelik tutum testlerinin deney ve kontrol grubundaki öğrencilerin ortalama tutum puanları arasında anlamlı farklılıklar olduğunu göstermiştir. EBA destekli öğretimin matematik dersine karşı tutumu olumlu yönde etkilediği söylenebilir.

Bu konuya benzer olduğu düşünülebilecek başka araştırmalarda, örneğin, Türkmen ve Soybaş (2019) çalışmalarında, oyun temelli öğrenmenin 5. Sınıf öğrencilerinin Matematik dersindeki başarılarına ve tutumlarına etkisini araştırmıştır. Bu amaç doğrultusunda "Kesirler" ünitesi ders planı oyunlaştırılmış olarak hazırlanmış ve öğretim materyali olarak da Eğitim Bilişim Ağı oyunları kullanılmıştır. Araştırmanın deney grubunda 28 öğrenci, kontrol grubunda 22 öğrenci olmak üzere toplam 50 öğrenci 
bulunmaktadır. Nicel ve nitel araştırma yöntemlerin bir arada kullanıldığı bu araştırmada karma yöntem kullanılmıştır. Nicel araştırma yöntemi olarak deneysel araştırma yöntemlerinden, ön test - son test kontrol gruplu yarı deneysel desen kullanılmıştır. Sonuç olarak deney ve kontrol gruplarında öğrenim gören öğrencilerin başarı ve tutum puanları arasında istatistiksel olarak anlamlı bir farklılık bulunmamıştır. Deney grubu öğrencilerinin kendi içinde başarıları, kontrol grubundaki öğrencilere göre daha fazla artı̧̧ göstermiştir.

Budiyar (2018) çalışmasında FATİH Projesi kapsamında 7.sınıf öğrencilerinin eşitlik ve denklem konusunda Z-kitap uygulamalarının matematik dersine karşı tutum ve motivasyonları (isteklendirme) ne gibi etkisinin olduğunu incelemeye çalışmıştır. Araştırmada yarı deneysel model kullanılmış, öğretim yöntemi olarak Z-kitap uygulaması kullanılmıştır. Veri toplamak için matematik tutum ölçeği ön test ve son test olarak uygulanmıştır. Verilere göre, Z-kitap uygulamasının matematiğe yönelik tutumlarına istatistiksel anlamda etki ettiğini bulmuştur.

Yağdıran (2018) araştırmalarında teknoloji destekli öğrenme ortamlarında 11.sınıf öğrencilerinin matematik dersine olan ilgilerine yönelik bir çalışma yapmıştır. Araştırmanın sonucunda matematik müfredatında bulunan kazanımlara yönelik etkinliklerde, eğitim teknolojilerinin kullanımı matematik dersine yönelik tutumu anlamlı bir şekilde etkilemiştir. Bu çalışmada Yağdıran'ın çalışması ile uymludur.

Beşinci Sınıf matematik dersinin "Doğal sayılar, Doğal sayılarda işlemler" konularının öğrencilerin aktif katılımını sağlamada çevrim içi EBA destekli ortamın konu anlatımı, alıştırma, tarama testi ve öğretmene özel içerikleri çerçevesinde hazırlanan etkinliklerle ve geliştirilen bu konu anlatımlarına uygun çalışma kağıtları ile zenginleştirildiğinde öğretim programındaki kazanımlara yönelik anlamlı bir etki oluşturduğu ifade edilebilir. Bu bağlamda okullarımızda teknolojinin getirdiği bu firsatların aktif kullanımına yönelik önemin verilmesi düşünülmelidir.

Günümüzde kablosuz bağlantının yaygınlaşmış, kablosuz bağlantı ve taşınabilir cihazlar (örneğin, dizüstü ve tablet bilgisayarlar) öğretmenlerin teknolojiyi öğretime katmasına yardımcı olmaktadır. Cep telefonları birçok işlevi yerine getirebilen hale dönüşmüş ve böylece öğrenciler farklı uygulamaları az sayıda donanımla gerçekleştirme olanakları sağlanmaya başlanmıştır. Uzaktan eğitim ve çevrimiçi öğrenim (online learning) olanakları artmaktadır. Sanal sınıflar oluşturulmaya başlanmış e-öğrenim önceki sınıf düzeylerini de (orta ve İlkokul) içine alacak şekilde genişlemiştir. Son olarak, teknoloji daha da elverişli hale geldikçe geleneksel öğretimin yerini yavaş yavaş daha az sınıf içi öğretim ve daha fazla elektronik iletişime dayanan bir öğretim modeline yönlendiğimizi söyleyebiliriz. EBA bu konuda iyi bir açılımdır. Bu açılımda videolardaki bağlamsal problemlere uygun çalışma kâğıtlarının düzenlenmesi pekiştirme açısından düşünülmelidir.

Çalışma EBA destekli 5. Sınıf öğrencilerinin "doğal sayılar ve doğal sayılarda işlemler" ünitesinin öğretilmesinde bilgisayarlı (akıllı) tahta kullanımının etkisinin araştırılması şeklinde tekrarlanabilir. Aynı çalışma EBA’nın öğrencilerin matematik özyeterliliklerine etkisini, özdüzenleme becerilerine etkisini araştırma yoluna gidebilir.

Araştırma sonuçları çalışmanın yapıldığı bölgenin ve koşullarının iç dinamikleri doğrultusunda da ele alınmalıdır. Yapılan öneriler de bu çerçevede değerlendirilmelidir. Bulgular teknolojik uygulamaların öğrenmeyi desteklediğini, matematiğe yönelik tutumu geliştirdiğini gösterse de öğrenme üzerinde ne kadar etkili olduğunu inceleyecek daha fazla araştırmaya ihtiyaç vardır.

Araştırılması gereken bir diğer konu da teknolojinin öğretmen ve öğrenciler üzerindeki motivasyonel tutum dışındaki etkileridir. Teknoloji ilerledikçe sunduğu öğrenme ve öğretim olanakları da genişleyecektir. Yeni ve gelişmiş yollardan bilgiye ulaşıp bilgiyi dönüştürma firsatlarını yakalayacağız. Mennon (2014), çocuklarda, beynin hipokampüsü ve prefrontal korteksi aritmetik gerçekleri işlemden geçirilirken, bellek temelli problem çözmeye katkısını yetişkinlerde görülen düzeyden daha etkili olduğunu söylemiştir. Aynı çalışmada hipokampüsün, yeni hatıraları biçimlendirmedeki rolünden dolayı bazı matematiksel gerçekleri ezberlendikten bir yıl sonra daha aktif şekilde ortaya çıktı̆̆ını tespit etmiş̧tir. Prosedürel stratejiler hafizaya alıırken daha çok çaba harcadığından, prosedürel strateji gerektiren problemler beynin daha fazla bölümünü aktive etmektedir.

Araştırmacılara aşağıdaki birtakım öneriler, süreçte fayda sağlayacaktır.

- Araştırmacıların çalışmayı ortaokul müfredatında bulunan diğer öğrenme alanlarındaki konular üzerinde yapabilmeleri teşvik edilmelidir.

- Ayrıca öğretmenlerin EBA'da kullanılan materyallerle ilgili üretimlerini teşvik edecek yarışmalar matematiğin öğrenme alanlarına göre düzenlenebilir.

- EBA'daki sınıf içi etkinlikleri arttırmak için çalışmalar yapılabilir. 
- EBA'daki sınav soruları ve çözümlü örneklerin sınıflamalarının yapılması ve arttırılması düşünülebilir.

- EBA’nın matematik eğitimindeki etkinliğini araştırmak için gelecekte farklı sınıf seviyelerinde çalışmalar yapılmalıdır.

- EBA destekli matematik öğretiminin etkisini arttırmak için kontrol gruplarına verilen geleneksel ev ödevlerine karşı deney grubuna e-içerik ve çalışma yaprakları EBA üzerinden gönderilebilir. Bunun için gruplara atama yapılmadan önce okul dışında çevrim içi olabilme durumlarına göre tayin yapılması bağımsız değişkenin etkisini arttıracaktır.

- EBA destekli öğretimin ilkokul, ortaokul ve lise düzeyindeki öğrencilerde etkileri incelenebilir.

- Aynı yaş grubunda bulunan farklı okul türlerindeki (Anadolu Liseleri, Fen Liseleri, İmam Hatip Liseleri, Meslek Liseleri, Kolejler vb.) öğrencilerde EBA destekli öğretimin etkilerine bakılabilir.

- Öğrencilerin EBA içeriği hakkında bilgi sahibi olabilmeleri ve kullanım becerilerini geliştirmelerine yönelik okullarda çalışmalar yapılabilir.

Günümüzdeki yeni nesil cep telefonlarının hepsi internet erişimli olduğundan, özellikle EBA'nın mobil uygulamasına kolaylıkla erişim sağlanabilmektedir. Bu bağlamda velilere EBA'nın mobil uygulamasının varlığından ve 3 GB'ye kadar ücretsiz olduğundan bahsetmek EBA kullanımını okul dışında da mümkün kılabilir. Mobil telefonların pahalı olması sadece bölgeler arası değil aynı il içindeki farklı yerleşim durumlarında sorun olmaya devam etmektedir.

Ortaokul öğrencilerinin EBA'yı okul dışı ortamlarda kullanmasına yönelik araştırmalar yapılmalıdır.

Öğretmenlerin, öğrencilerin EBA'yı daha aktif kullanmaları teşvik edilmelidir.

\section{Kaynakça}

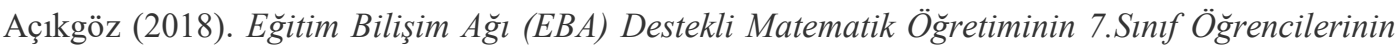
Akademik Başarısına Etkisi. Yüksek Lisans Tezi. Kastamonu Üniversitesi, Eğitim Bilimleri Enstitüsü, Kastamonu.

Akbaş, E. E. Eğitim Bilişim A $\breve{g}$ (EBA) Destekli Matematik Öğretiminin 5. Sınıf Kesir Konusunda Öğrenci Başarılarına Etkisi. Journal of Computer and Education Research, 7(13), 120-145.

Akgül, M. (2014). Dinamik geometri yazılımı kullanımının sekizinci sınıf öğrencilerinin dönüşüm geometrisi konusundaki başarısı, geometrik düşünmesi ve matematik ve teknolojiye yönelik tutumları üzerine etkisi. Orta Doğu Teknik Üniversitesi, Sosyal Bilimler Enstitüsü, Ankara.

Al, U. \& Madran, O. (2004). Web based distance education systems: Required features and standards. Bilgi Dünyas1, 5(2), 259-271.

Baki, A., (2018), Matematiği Ögretme Bilgisi, Pegem Akademik Yayıncılık, Ankara.

Bilgin, E. (2018). Ortaöğretim Matematik Dersi Öğretim Programı Veri Alt Öğrenme Alanına Yönelik Farklı Teknolojik Destekli Ögrenme Ortamlarının Değerlendirilmesi. Doktora Tezi. Atatürk Üniversitesi, Eğitim Bilimleri Enstitüsü, Erzurum.

Budiyar, S. (2018). Fatih Projesi Kapsamindaki Z-kitap Uygulamasinin 7. Sinif Öğrencilerinin Matematik Dersine Yönelik Tutum, Motivasyon ve Başarisina Etkisi. Yüksek Lisans Tezi. Afyon Kocatepe Üniversitesi, Fen Bilimleri Enstitüsü, Afyon.

Büyüköztürk, Ş. (2001). Deneysel desenler: Öntest sontest kontrol gruplu desen ve veri analizi. Ankara: Pegem Akademi.

Çakır, H. (1999). Bilgisayar destekli eğitimde grafik ve animasyon tekniklerinin kullanılması. (Yayımlanmamış yüksek lisans tezi). Gazi Üniversitesi Fen Bilimleri Enstitüsü, Ankara. 
Cengiz, N. (2017). Teknoloji Destekli Matematik Öğretiminin Öğrencilerin Matematik Başarısına ve Matematik Kaygısına Etkisi. Yüksek Lisans Tezi. Gazi Antep Üniversitesi, Eğitim Bilimleri Enstitüsü, Gazi Antep.

Ekici, M., Arslan, İ., \& Tüzün, H. (2016). Eğitim Bilişim Ağ1 (EBA) web portalı kullanılabilirliğinin göz izleme yöntemiyle değerlendirilmesi. A. İşman, H. F. Odabaşı ve B. Akkoyunlu (Editörler) Eğitim teknolojileri okumaları 2016 içinde (273-296). Ankara: Salmat Basım Yayıncılık.

Kelly, S. L. (2018). The impact of Khan Academy math remediation on ninth grade student achievement. (Unpublished doctoral dissertation). Liberty University, Lynchburg,VA

Karasar, N. (2007), Bilimsel Araştırma Yöntemleri, 17. Basım, Nobel Yayın Dağıtım.Ankara

Mayer, R. E. (1996). Learners as information processors: Legacies and limitations of educational psychology's second metaphor. Educational Psychologist, 31, 151-161.

Murphy, R. Gallagher, L., Krumm, A., Mislevy, J., Hafter, A., \& Park, M. (2014). Research on the use of Khan Academy in schools. Menlo Park, CA: SRI Education. Retrieved July, 16, 2015.

Nazlıçiçek, N. ve Erktin, E. (2002). İlköğretim Öğretmenleri İçin Kısaltılmış Matematik Tutum Ölçeği. V. Ulusal Fen Bilimleri ve Matematik Eğitimi Kongresi Bildiri Kitapçı̆̆ı (16-18 Eylül 2002), Ankara: Orta Doğu Teknik Üniversitesi. 860-865

Menon, V. (2014). New research sheds light on how children's brains memorize facts. Stanford Medicine News Center. http://med.stanford.edu/news/all-news/2014/08/new-research-shedslight-on-how-childrens-brains-memorize-facts.html

Seery M. K. and McDonnell C., (2013), The application of technology to enhance chemistry education, Chem. Educ. Res. Pract., 14, 227-228.

Türkmen, G. P., \& Soybaş, D. (2019). The effect of gamification methodology on students' achievements and attitudes towards mathematics. Bartın University Journal of Faculty of Education, 8(1), 258-297.

Tüysüz, C. \& Aydın, H. (2007). Web tabanlı öğrenmenin ilköğretim okulu düzeyindeki öğrencilerin tutumuna etkisi. Pamukkale Üniversitesi Eğitim Fakültesi Dergisi, 22(22), 73-78.

Van De Walle, J. A., Karp, K. S. ve Bay-Williams, J. M. (2014). Ilkokul ve Ortaokul Matematiği Gelişimsel Yaklaşımla Öğretim. (Çeviri Editörü: Soner Durmuş). Ankara: Nobel Akademik Yayıncilık.

Vandewaetere, M. \& Clarebout, G. (2013). Cognitive Load of Learner Control: Extraneous or Germane Load?, Education Research International, Volume 2013, Hindawi Publishing Corporation

Yağdıran (2018). Teknoloji Destekli Öğrenme Ortamlarinda 11. Sinif Öğrencilerinin Matematiksel Düşünme Süreçlerinin Incelenmesi. Yüksek Lisans Tezi. Gazi Üniversitesi, Eğitim Bilimleri Enstitüsü, Ankara.

Yeniad, M. (2006). Uzaktan eğitimde kullanılmak üzere web tabanlı bir portal yazılımı geliştirme. Yüksek Lisans Tezi. Çukurova Üniversitesi Sosyal Bilimler Enstitüsü, Adana 

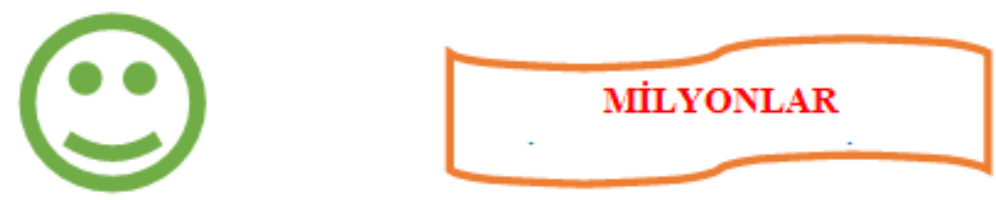

Milyonlar etkinliğimizde, ülkemizin en kalabalık 3 şehrin nüfuslarmı okumayı öğreneceğiz.

Türkiye İstatistik Kurumunun 2019 verilerine göre Türkiye'nin toplam nüfusu:

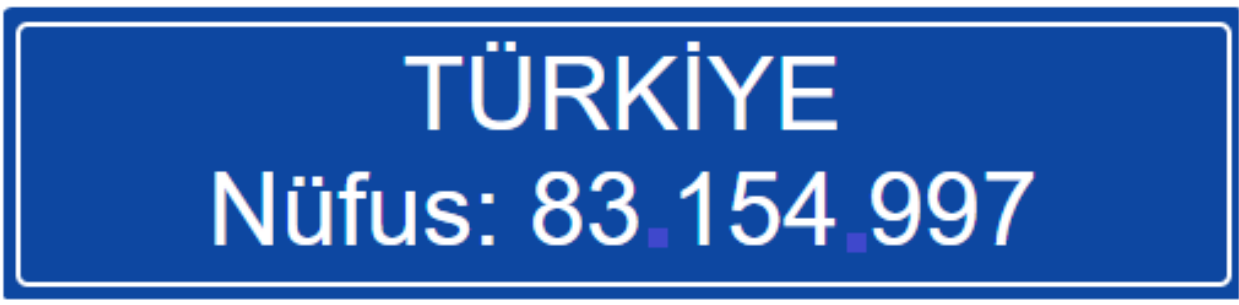

İllere göre en kalabalık 3 şehrimizin nüfusu ise aşağıdaki gibidir:

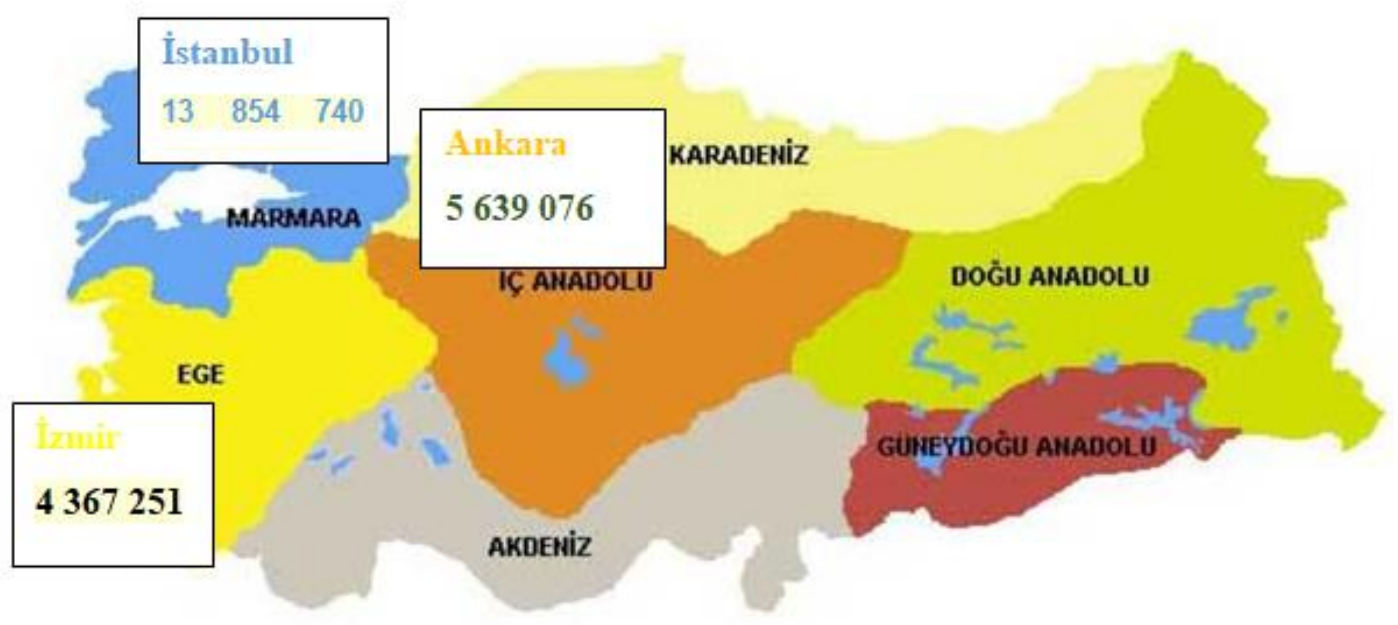


İstanbul İlimizin Nüfusu: 13854740

Bölüklerine ayıralım ve isimlerini yazalım.

\section{$\underbrace{13} \underbrace{854} \underbrace{740}$}

Sayı ve basamak değerlerini bulalım:

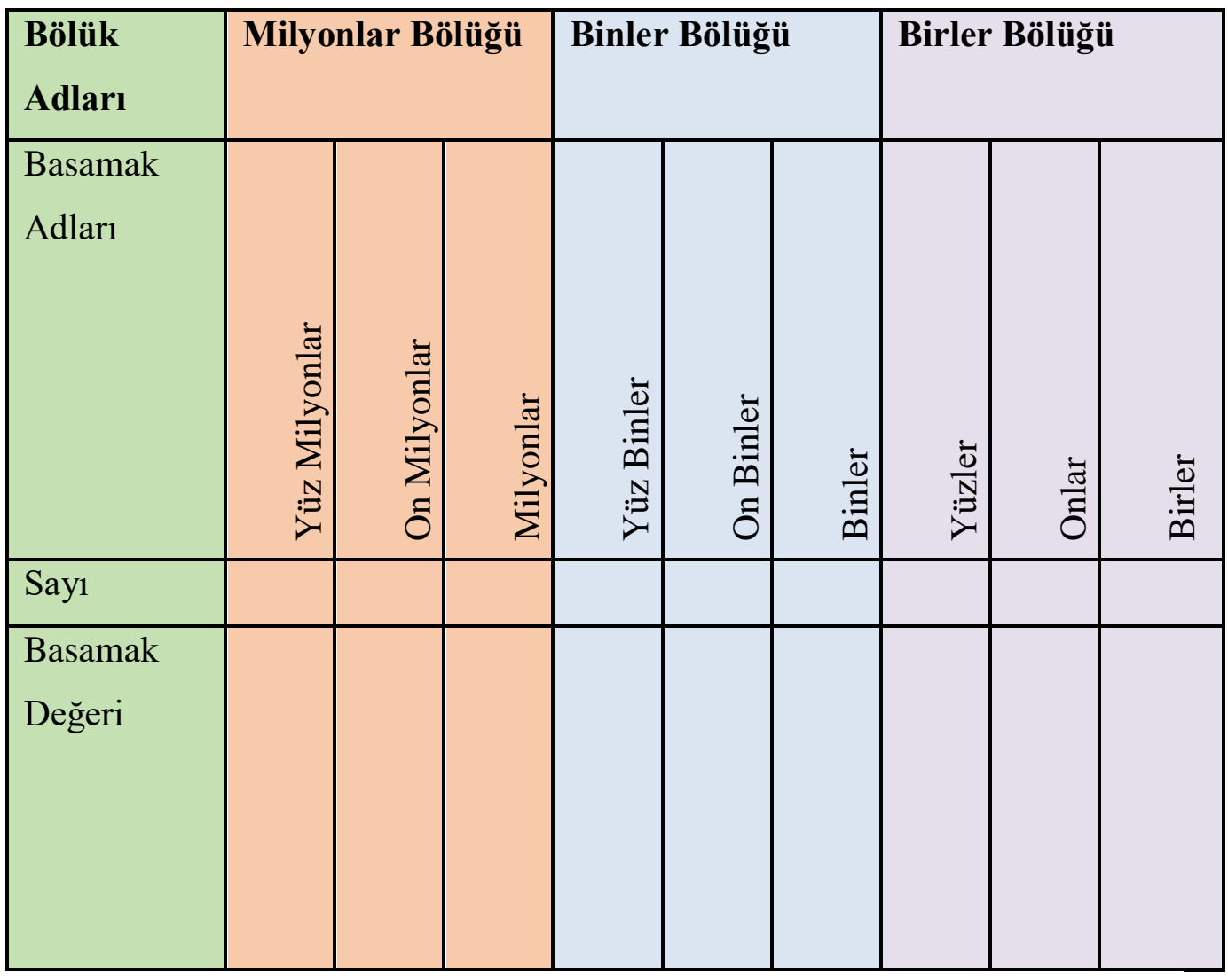


Ankara İlimizin Nüfusu: 5639076

Bölüklerine ayıralım ve isimlerini yazalım.

\section{6}

Sayı ve basamak değerlerini bulalım:

\begin{tabular}{|c|c|c|c|c|c|c|c|c|c|}
\hline Bölük & Milyo & $\overline{r B}$ & & Binler & ölüğ & & Birle & ölüğ & \\
\hline $\begin{array}{l}\text { Basamak } \\
\text { Adları }\end{array}$ & 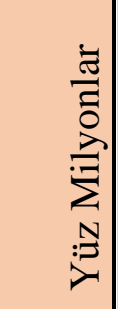 & 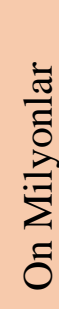 & $\begin{array}{l}\frac{\bar{z}}{\Xi} \\
\bar{\partial} \\
\bar{\Sigma}\end{array}$ & 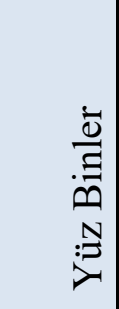 & $\begin{array}{l}\stackrel{\overline{0}}{\Xi} \\
\tilde{0} \\
\tilde{0}\end{array}$ & 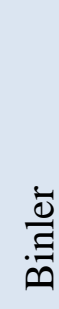 & $\underset{: \bar{N}}{: \mathcal{N}}$ & $\frac{\bar{z}}{\tilde{\Xi}}$ & $\stackrel{\bar{\oplus}}{\bar{\oplus}}$ \\
\hline Sayı & & & & & & & & & \\
\hline $\begin{array}{l}\text { Basamak } \\
\text { Değeri }\end{array}$ & & & & & & & & & \\
\hline
\end{tabular}

Milyonlu Sayılar

Aşağıda verilen sayıların okunuşunu ve okunuşları verilen sayıları karşılarına yazınız.

\begin{tabular}{|l|l|}
\hline 1. 15298576 & On beş milyon iki yüz doksan sekiz bin beş yüz yetmiş altı \\
\hline 2. 27456109 & \\
\hline 3. 149556223 & \\
\hline 4. 8573129 & \\
\hline 5. 486259357 & Beş milyon yedi yüz yetmiş dört bin yüz üç. \\
\hline 6. $\mathbf{5 7 7 4} 103$ & $\begin{array}{l}\text { Yedi yüz yetmiş sekiz milyon altı yüz altmış dört bin yüz kırk } \\
\text { yedi. }\end{array}$ \\
\hline 7. & Altı yüz doksan bir milyon iki yüz altmış bin iki yüz yedi. \\
\hline $\mathbf{8 .}$ & Bir milyon sekiz yüz elli bir bin otuz üç. \\
\hline $\mathbf{9 .}$ & Yüz altı milyon elli sekiz bin üç yüz altmış dört. \\
\hline $\mathbf{1 0 .}$ &
\end{tabular}


Ek 2.

\section{Sınıf Doğal Sayılar ve Doğal Sayılarda İşlemler Ön test- Son Test}

Soru 1

\begin{tabular}{|l|l|l|l|l|l|l|l|l|}
\hline 3 & 8 & 1 & 9 & 0 & 6 & 4 & 5 & 2 \\
\hline
\end{tabular}

Yukarıdaki rakamların yazıldığı kartlarla 9 basamaklı en küçük sayıyı yazmak isteyen Ayşe'nin oluşturduğu sayının okunuşu nedir?

A) Dokuz yüz seksen altı milyon üç yüz kırk beş bin yüz iki

B) İki yüz bir milyon üç yüz elli dört bin altı yüz seksen dokuz

C) On milyon iki yüz otuz dört bin beş yüz atmış sekiz

D) Yüz iki milyon üç yüz kırk beş bin altı yüz seksen dokuz

Soru2
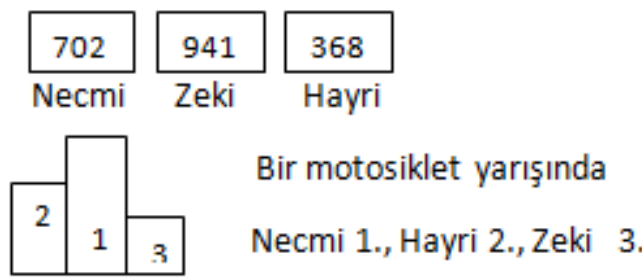

Olmuştur. Kürsüye çıkan yarışmacıların göğüs numaraları yukarıda verilmiştir. Buna göre kürsüdeki yarışmacıların gögüs numaralarının soldan sağa doğru okunuşu nedir?

A) Üç yüz atmış sekiz milyon yedi yüz iki bin dokuz yüz kırk bir

B) Yedi yüz iki milyon dokuz yüz kırk bir bin üç yüz atmış sekiz

C) Dokuz yüz kırk bir milyon yedi yüz iki bin üç yüz atmış sekiz

D) Yedi yüz iki milyon üç yüz atmış sekiz bin dokuz yüz kırk bir

\section{Soru3}

\section{$7468 a a 42$}

Yukarıda verilen doğal sayının sayı değerleri toplamı $47^{\prime}$ dir. Buna göre a yerine aşağıdakilerden hangisi gelmelidir?
A) 4
B) 5
C) 6
D) 8

Soru4

Milyonlar bölüğündeki rakamların toplamı 7, binler bölüğündeki rakamların toplamı 14 ve birler bölüğündeki rakamların toplamı 11 olan aşağıdaki doğal sayılardan hangisi en büyüktür?
A) 403680461
B) 610572740
C) 601257074
D) 610608164

Soru5

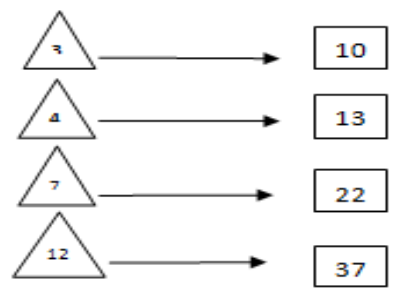

Ali yukarıdaki kuralı kullanarak $\triangle$ kutusunun içindeki sayıdan $\square$ kutusunun içindeki sayıyı elde etmektedir.

Buna göre bu kural nedir?
A) îki katının iki fazlası
B) Üç katının bir fazlası
C) Dört katının bir eksiği
D) Üç katının üç fazlası

Soru6
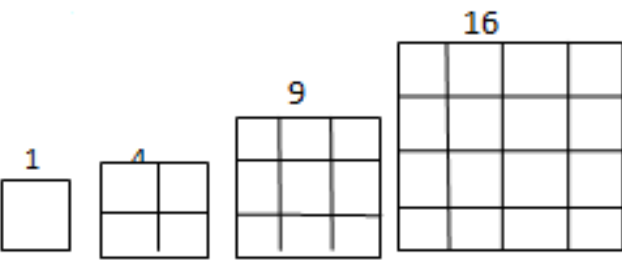

1.adım 2.adım

3.adım

Yukarıdaki her bir adımdaki birim kare sayısı verilen örüntüye göre aşağıdakilerden hangisi herhangi bir adımdaki kare sayısı olabilir?
A) 17
B) 34
C) 36
D) 41 


\section{Soru7}

Ali'nin kumbarasında 50 TL ve Ayşe'nin kumbarasında $40 \mathrm{TL}$ vardı. Ayşe her gün kumbarasından $5 \mathrm{TL}$, Ali ise $10 \mathrm{TL}$ harcamaktadır. Buna göre kaç gün sonra kumbaralarındaki para miktarları eşit olur?
A) 2
B) 3
C) 4
D) 5

Soru8

Hangi seçenekteki örüntünün kuralı diğerinden farklıdır?
A) $3-7-11-15$
B) $4-8-12-16$
C) $6-10-14-18$
D) $11-16-21-26$

Soru9

Şehit Öğretmenler Ortaokulunda geçen yıl 423 erkek 514 kız öğrenci vardı. Bu sene 469 'u erkek olmak üzere 1243 öğrenci bulunmaktadır. Bu seneki kız öğrenci sayısı geçen yılki kız öğrenci sayısından kaç fazladır?
A) 260
B) 270
C) 280
D) 290

Soru 10

Harun, Reşit ve Vahit aynı evde ya kardeştir. Hepsi birlikte Harun'un okuluna 20 varmaktadır. Daha sonra Reşit ve Vahit, Reşit'ir 15 dakikada varmıştır. Vahit'in Reşit'in okulund okuluna gitmesi 10 dakika sürdüğüne gör okluna 09:00'da ulaşması için üç kardeş evc kaçta çıkmalıdır?
A) $07: 45$
B) 08:00
C) $08: 10$
D) 08

Soru11

11 araçtan oluşan bir düğün konvo araçlara dağıtılmak üzere 103 tane mendil । Tüm araçlara eşit sayıda mendil dağıtılabilme kaç mendile daha ihtiyaç vardır?
A) 2
B) 5
C) 7
D) 10

\section{Soru12}

Yeliz elinde $20 \mathrm{~cm}$ uzunluğundaki bir cetvelle kendi sırasının boyunu ölçmek istiyor. Sıranın uzunluğu cetvelin boyunun $5 \mathrm{~cm}$ fazlasının 3 katı kadar olduğunu bildiğine göre sıranın boyunu ölçmek için hangi işlemi yapmalıdır?
A) $20 \times 30+5$
B) $(3+5) \times 20$
C) $(20+5) \times 3$
D) $(20+3) \times 5$

Soru13

$$
\text { 81: } \square=\square
$$

Yukarıdaki işlemde $\square$ aynı sayıyı temsil etmektedir. $\square$ yerine gelmesi gereken sayı kaçtır?
A) 9
B) 10
C) 11
D) 12

Soru14

$$
24: 6=\square: 7
$$

Yukarıdaki sayı ifadesinde $\square$ hangi sayıya karşlık gelmektedir?
A) 15
B) 21
C) 25
D) 28

Soru15

Bir baba üç çocuğunu sinemaya götürmek istemektedir. Bir yetişkin bileti bir çocuk biletinin 3 katı kadardır. Baba 4 bilet için $120 \mathrm{TL}$ ödediğine göre her bir çocuk bileti kaç TL'dir?
A) 10
B) 20
C) 30
D) 40

Soru16

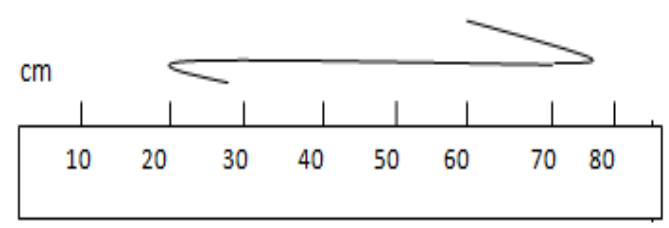

Cetvelin üzerindeki ip düz bir hale getirilirse ipin uzunluğuna en yakın değer aşağıdakilerden hangisidir?
A) 75
B) 85
C) 95
D) 100 


\section{Soru 17}

Ayşe'nin 15 tane ipi, 45 tane mavi boncuğu ve 54 tane sarı boncuğu vardır. Ayşe 1 ip, 6 tane mavi boncuk ve 8 tane sarı boncukla bir bileklik yapmaktadır. Ayşe bütün bileklikleri aynı şekilde yaparsa kaç bilekliği olur?
A) 5
B) 6
C) 7
D) 8

\section{Soru18}

Aşağıda bir çarpma işleminin zihinden yapııışının işlem basamakları verilmiştir. Bu verilen

$57=50+7 \quad \begin{aligned} & \text { işlem aşağıdakilerden } \\ & 50 \times 13=650 \\ & \text { hangisi olabilir? }\end{aligned}$

\section{Soru 19}

$$
\begin{aligned}
27+18+43 & =(27+43)+18 \\
& =70+18 \\
& =88
\end{aligned}
$$

Yukarıda verilen işlem aşağıdaki yöntemlerden hangisi kullanılarak yapılmıştır?
A) Kolay Toplanan Sayılardan Başlama
B) Onlukları Ve Birlikleri Ayırarak Toplama
C) Üzerine Sayarak Toplama
D) Sayıları 10'u Referans Olarak Toplama

Soru20

\section{A marka 87544 TL \\ B marka $44318 \mathrm{TL}$}

Yukarıda iki farklı otomobilin fiyatları görülmektedir. Bu fiyatlar en yakın binliğe yuvarlandığında iki marka arasındaki fiyat farkı ne olur?
A) 44000
B) 145000
C) 46000
D) 47000

\section{Soru21}

$$
\begin{array}{lll}
\text { Yemek Listesi } & & \text { Sipariş } \\
\text { Çorba }=6 \mathrm{TL} & & \text { Çorba }: \mathrm{x} \text { x } \\
\text { Kebap }=17 \mathrm{TL} & & \text { Kebap : x/ } \\
\text { Tatlı }=8 \mathrm{TL} & & \text { Tatlı : x x/ } \\
\text { Salata }=5 \mathrm{TL} & & \text { Salata }: \mathrm{x} \text { x x }
\end{array}
$$

Yukarıda verilen listeye göre verilen sipariş kaç lira tutar?
A) 145
B) 150
C) 151
D) 153

Soru22

$4500: 50 \quad$ İşleminin sonucunu bulmak için hangisi yapılırsa yanlış olur?

A) 4500 sayısında iki sıfır silinip elde edilen sonuç 2 ile çarpilırsa

B) 45 sayısı 5' e bölünüp elde edilen sonucun sağına bir sıfır eklenirse

C) 4500 sayısı 10'a bölünüp elde edilen sonuç 5'e bölünürse

D) 450 sayısı 5'e bölünüp elde edilen sonucun sağına iki sıfır eklenirse

\section{Soru23}

\section{4 öğrenci 18 kişilik sınıflara}

yerleştiriliyor. Tüm öğrenciler sınıfa yerleştiğinde 14 öğrenci ayakta kalıyor. Buna göre okulda kaç derslik olduğunu veren matematiksel ifade hangisidir.
A) $(374: 14)+18$
B) $(374: 18)+14$
C) $(374-14): 18$
D) $(374-18) \times 14$

Soru24

$$
\begin{aligned}
810.000: 9000 & =A \\
B: 300 & =150 \\
800.000: C & =16
\end{aligned}
$$

Yukarıda verilen bölme işlemlerine göre $A, B$ ve $C$ yerine yazılması gereken sayllar sırasıyla hangisidir?
A) $90-50-500$
B) $900-500-50$
C) $90-45000-50000$
D) $900-45-50$ 


\section{Soru 25}

Doğal sayılarla yapılan bir bölme işleminde bölen 7 olduğuna göre kalanın alabileceği değerler toplamı kaçtır?
A) 18
B) 21
C) 24
D) 30

Soru 26

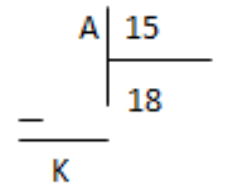

Yandaki bölme işleminde A doğal sayısı en fazla kaçtır?
A) 270
B) 275
C) 281
D) 284

\section{EK 4'ün Devamı}

\section{Soru 27}

$$
169=12^{2}+\square 2
$$

Yukarıdaki eşitlikte $\square$ yerine yazılacak doğal sayı nedir?
A) 6
B) 5
C) 4
D)3

Soru28

$$
\begin{aligned}
& \mathrm{K} \text { L M Yanda verilen çarpma } \\
& \mathrm{x} \quad \mathrm{N} 6 \quad \text { işlemine göre } \mathrm{K}+\mathrm{L}+\mathrm{M}+\mathrm{N} \\
& \text { toplamı kaçtır? } \\
& \begin{array}{r}
620 \\
\hline 6944
\end{array}
\end{aligned}
$$
A) 11
B) 12
C) 13
D) 14

Soru29

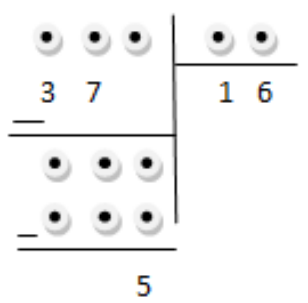

Üstteki bölme işlemine göre bölünen sayı kaçtır?
A) 590
B) 597
C) 604
D) 619

Soru30

$$
\begin{aligned}
A \times A & \times A=17^{3} \\
11 \times 11 & =11^{B}
\end{aligned}
$$

Yukarıda verilen işlemlere göre $A+B$ kaçtır?
A) 19
B) 21
C) 28
D) 6

Soru31

Bir baba üç çocuğunu sinemaya götürmek istemektedir. Bir yetişkin bileti bir çocuk biletinin 3 katı kadardır. Baba 4 bilet için $120 \mathrm{TL}$ ödediğine göre her bir çocuk bileti kaç TL'dir?
A) 10
B) 20
C) 30
D) 40

Soru32

Bir okuldaki derslikler en fazla 22 öğrenci almaktadır. 1100 öğrencisi bulunan bu okulun tüm öğrencileri kayit yapabilmesi için en az kaç dersliğe intiyacı vardır? Sorusunu nasıl hesaplarsınız?
A) $1100^{\prime}$ ü 22 ile topla
B) $1100^{\prime}$ den $22^{\prime}$ yi çıkar
C) $1100^{\prime}$ ü $22^{\prime}$ ye böl
D) $1100^{\prime}$ ü 22 ile çarp 